\title{
The Soil Leaching of Minerals from Mae Moh, Lampang, Thailand
}

\author{
$\underline{\text { Pajaree Thongsanit }}^{1,2}$ and Witchaya Imkrajang ${ }^{2}$ \\ ${ }^{1}$ Lecturer of Center of Excellence for Energy Technology and Environment and \\ ${ }^{2}$ Department of Civil Engineering, Faculty of Engineering, Naresuan University, Phitsanulok, \\ Thailand 65000
}

\begin{abstract}
The study of the concentrations of minerals or nutrients in the soil deposited by acid rain at Mae Moh power plant area, Lampang Province, Northern part of Thailand. Lampang Province is the third largest town in northern Thailand. The city is still growing rapidly as trading and transportation center. The soil samples were analyzed in the farming area near Mae Moh power plant. The soil sampling point was located in Ban Mae Chang, south of the Mae Moh power plant. The samples were analyzed the physical and chemical characteristics of soil. The analytical parameters were calcium, magnesium, potassium. The leaching of minerals in soil by syntactic acid rain were different $\mathrm{pH}$ values. The minerals were not exceeding soil quality standards for residential and agriculture land use.
\end{abstract}

Keywords: Soil Leaching, Minerals, Lampang, Thailand

\section{Introduction}

Lampang Province is the third largest town in northern Thailand. The city is still growing rapidly as trading and transportation center. It offers much of the historic interest of Lanna as well as Chiangmai, but without the overt commercialization. Located in the heart of the North, Lampang is also a good base for excursions and travel within northern Thailand. ${ }^{1}$ Mae Moh power plant was located in Mae Moh district, Lampang province. Currently, total capacity of the electricity generating of Mae Moh power plant was 2,625 MW with 13 units of the generator. The capacity of Mae Moh power plant was around twenty percentage of the capacity electric power of the Thailand. They used lignite coal with high sulfur average of three percent by weight to produce electricity. The sulfur dioxide emissions of power plant were 150 tons / hour. ${ }^{2}$ The deposition of acid from sulfur dioxide has more acidic soil nutrients such as calcium, magnesium, potassium some plants potassium loss due to leach into the subsoil. The objective is to study of concentrations of nutrients accumulate in soil erosion by acid rain. This research studied the concentration of dissolved nutrients around the Mae Moh power plant. There were affected of the crops grown for consumption.

\section{Research Method}

Research Location: The effects of acid deposition on the leach minerals in the soil were studied. The study area was south of Mae Moh power plant, namely in Ban Mae Chang community. Ban Mae Chang locate three kilometer southern of Mae Moh power plant. Bang Mae Chang set in Mae Moh district, Lampang Province. The numbers of house in Ban Mae Chang were 173, The main of occupation of Ban Mae Chang people were famers and constructors. ${ }^{3}$ Soil samples taken from Ban Mae Chang communities around the Mae Moh power plant. Soil samples were analyzed the physical and chemical characteristics of the soil. The parameters of the soil were $\mathrm{pH}$, soil moisture, sizing of a grain of soil, organic matter, and nitrogen. The analytical parameters were calcium, magnesium, potassium. The leaching of minerals in soil by acid rain were different $\mathrm{pH}$ values of $4.5,5.0,5.5$, 6.0 and 6.5 .

\section{Results and Discussions}

The physical and chemical properties of soil samples were shown. $\mathrm{pH}$ of soil at Ban Mae Chang at the depth of underground level at $10-20 \mathrm{~cm}$ and $20-30 \mathrm{~cm}$ were 4.63 and 4.75 . Soil samples were lower than 7.0 , the 
normal level of $\mathrm{pH}$ in soil was 5-8. The soil moistures were $0.26 \%$ and $1.18 \%$ of soil of underground level $10-20$ $\mathrm{cm}$ and $20-30 \mathrm{~cm}$. The moistures were very low. The grains of soil in upper level were big size. There were large gaps in the soil. The air will be in these gaps more than water. The organic matter in the soil was $0.98 \%$ and $0.76 \%$ of the soil of underground level $10-20 \mathrm{~cm}$ and $20-30 \mathrm{~cm}$. The organic matter in these soils was low in the soil class. In the generally the organic matter was $1-6 \%$ by weight of the soil. The organic matter degraded over time of land use of farm. The decomposition of organic matter is lost from the soil in the form of $\mathrm{CO}_{2}$ and other gases, the amount of organic matter in the soil decreases. The organic nitrogen was low level at 0.3-0.4\% of soil. The soil could not absorb water. Organic nitrogen leached through under ground level. The land could not useful for plants.

The calcium, magnesium and potassium in the soil at Ban Mae Chang at the depth of underground level at 10-20 cm and 20-30 cm and the concentration of minerals of soils $\mathrm{mg}$ per $\mathrm{kg}$ of soil showed in table 1 and 2.

TABLE I: The calcium, magnesium and potassium in the soil at Ban Mae Chang

\begin{tabular}{|c|c|c|c|}
\hline DEPTH & Calcium (mg) & Magnesium (mg) & Potassium (mg) \\
\hline $10-20 \mathrm{~cm}$. & 1782 & 1828 & 715 \\
\hline $20-30 \mathrm{~cm}$. & 318 & 361 & 1253 \\
\hline
\end{tabular}

TABLE II: The concentrations of calcium, magnesium and potassium in the soil at Ban Mae Chang

\begin{tabular}{|c|c|c|c|}
\hline DEPTH & $\begin{array}{c}\text { Calcium } \\
(\mathrm{mg} / \mathrm{kg} \text { of soil })\end{array}$ & $\begin{array}{c}\text { Magnesium } \\
(\mathrm{mg} / \mathrm{kg} \text { of soil })\end{array}$ & $\begin{array}{c}\text { Potassium } \\
(\mathrm{mg} / \mathrm{kg} \text { of soil })\end{array}$ \\
\hline $10-20 \mathrm{~cm}$. & 280 & 288 & 113 \\
\hline $20-30 \mathrm{~cm}$. & 50 & 57 & 197 \\
\hline
\end{tabular}

The analytical parameters were calcium, magnesium and potassium. The leaching of minerals in soil by syntactic acid rain were different $\mathrm{pH}$ values. $\mathrm{pH}$ was $4.5,5.0,5.5,6.0$ and 6.5. The calcium in the soil leached by acid rain showed in table 3,4 and 5. The highest leach of calcium, magnesium and potassium in the soil was $\mathrm{pH}$ of rain at 5.5, 4.5 and 4.5 .

TABLE III: The leaching of calcium in soil by acid rain were different $\mathrm{pH}$ values.

\begin{tabular}{|c|c|c|c|c|c|c|}
\hline & \multirow[b]{2}{*}{$\begin{array}{c}\text { Calcium } \\
\text { in soil }(\mathrm{mg})\end{array}$} & \multicolumn{3}{|c|}{$\begin{array}{l}\text { The leaching of calcium } \\
\text { in soil (mg) }\end{array}$} & \multirow{2}{*}{$\begin{array}{c}\text { Calcium } \\
\text { residual } \\
\text { in Soil } \\
(\mathrm{mg})\end{array}$} & \multirow{2}{*}{$\begin{array}{l}\text { Concentration } \\
\text { of residual } \\
\text { calcium } \\
(\mathrm{mg} / \mathrm{kg})\end{array}$} \\
\hline & & $\begin{array}{l}\text { First } \\
\text { time }\end{array}$ & $\begin{array}{l}\text { Second } \\
\text { time }\end{array}$ & $\begin{array}{l}\text { Third } \\
\text { time }\end{array}$ & & \\
\hline $\mathrm{pH} 4.5$ & 1050 & 13.70 & 2.77 & 1.80 & 1032 & 162 \\
\hline pH 5.0 & 1050 & 8.72 & 4.74 & 2.67 & 1034 & 163 \\
\hline $\mathrm{pH} 5.5$ & 1050 & 16.81 & 6.12 & 6.45 & 1021 & 161 \\
\hline $\mathrm{pH} 6.0$ & 1050 & 17.42 & 0.59 & 4.48 & 1027 & 162 \\
\hline pH 6.5 & 1050 & 29.31 & - & - & - & - \\
\hline
\end{tabular}


TABLE IV: The leaching of magnesium in soil by acid rain were different $\mathrm{pH}$ values.

\begin{tabular}{|c|c|c|c|c|c|c|}
\hline & \multirow{2}{*}{$\begin{array}{l}\text { magnesium } \\
\text { in soil } \\
(\mathrm{mg})\end{array}$} & \multicolumn{3}{|c|}{$\begin{array}{c}\text { The leaching of magnesium } \\
\text { in soil } \\
\text { (mg) }\end{array}$} & \multirow{2}{*}{$\begin{array}{l}\text { magnesium } \\
\text { residual } \\
\text { in Soil } \\
(\mathrm{mg})\end{array}$} & \multirow{2}{*}{$\begin{array}{l}\text { Concentration } \\
\text { of residual } \\
\text { magnesium } \\
(\mathrm{mg} / \mathrm{kg})\end{array}$} \\
\hline & & $\begin{array}{l}\text { First } \\
\text { time }\end{array}$ & $\begin{array}{c}\text { Second } \\
\text { time }\end{array}$ & $\begin{array}{l}\text { Third } \\
\text { time }\end{array}$ & & \\
\hline $\mathrm{pH} 4.5$ & 1094 & 14.98 & 5.88 & 5.97 & 1068 & 168 \\
\hline pH 5.0 & 1094 & 6.49 & 3.87 & 2.41 & 1082 & 170 \\
\hline pH 5.5 & 1094 & 13.99 & 5.51 & 6.13 & 1069 & 168 \\
\hline $\mathrm{pH} 6.0$ & 1094 & 14.98 & 4.61 & 5.91 & 1069 & 168 \\
\hline $\mathrm{pH} 6.5$ & 1094 & 24.60 & - & - & - & - \\
\hline
\end{tabular}

TABLE V: The leaching of potassium in soil by acid rain were different $\mathrm{pH}$ values

\begin{tabular}{|c|c|c|c|c|c|c|}
\hline & \multirow{2}{*}{$\begin{array}{l}\text { potassium } \\
\text { in soil } \\
(\mathrm{mg})\end{array}$} & \multicolumn{3}{|c|}{$\begin{array}{c}\text { The leaching of potassium } \\
\text { in soil } \\
\text { (mg) }\end{array}$} & \multirow{2}{*}{$\begin{array}{l}\text { potassium } \\
\text { residual } \\
\text { in Soil } \\
(\mathrm{mg})\end{array}$} & \multirow{2}{*}{$\begin{array}{l}\text { Concentration } \\
\text { of residual } \\
\text { potassium } \\
(\mathrm{mg} / \mathrm{kg})\end{array}$} \\
\hline & & $\begin{array}{l}\text { First } \\
\text { time }\end{array}$ & $\begin{array}{l}\text { Second } \\
\text { time }\end{array}$ & $\begin{array}{l}\text { Third } \\
\text { time }\end{array}$ & & \\
\hline pH 4.5 & 984 & 0.16 & 0.28 & 0.95 & 983 & 154.53 \\
\hline pH 5.0 & 984 & 0.37 & 0.20 & 0.01 & 983 & 154.66 \\
\hline pH 5.5 & 984 & 0.49 & 0.09 & 0.16 & 983 & 154.63 \\
\hline pH 6.0 & 984 & 0.15 & 0.24 & 0.07 & 984 & 154.68 \\
\hline $\mathrm{pH} 6.5$ & 984 & 1.17 & - & - & - & - \\
\hline
\end{tabular}

\section{Conclusion}

The soil sampling point was located in Ban Mae Chang, south of the Mae Moh power plant. The samples were analyzed the physical and chemical characteristics of soil. $\mathrm{pH}$ of soil at Ban Mae Chang at the depth of underground level at $10-20 \mathrm{~cm}$ and $20-30 \mathrm{~cm}$ were 4.63 and 4.75 . The normal level of $\mathrm{pH}$ in soil was $5-8$. The moistures were very low. The nutrient of soil was low level. The analytical parameters were calcium, magnesium and potassium. The leaching of minerals in soil by syntactic acid rain were different $\mathrm{pH}$ values. The highest leach of calcium, magnesium and potassium in the soil was $\mathrm{pH}$ of rain at 5.5, 4.5 and 4.5, respectively.

\section{Acknowledgements}

This paper presentation was funded by the center of excellent for energy technology and environment, faculty of engineering, Naresuan University, Phitsanulok, Thailand. The research was funded by Office of the Higher Education Commission year 2015. The authors wish to thank Dr. Pilaipark Chumark and Mr. Chuchai Lornimitdee for their co-researchers. Thanks the staffs of the department of civil department engineering and staffs of air pollution research unit research for their support and provide research equipment.

\section{References}

[1] Lampang http://en.wikipedia.org/wiki/Lampang, access on 30 June 2015

[2] maemoh.egat.com/index_maemoh/access on 30 June 2015

[3] http://archive.lib.cmu.ac.th/full/T/2556/mem40256sc_ch1.pdf on 30 June 2015 